ISSN : 2252-8385

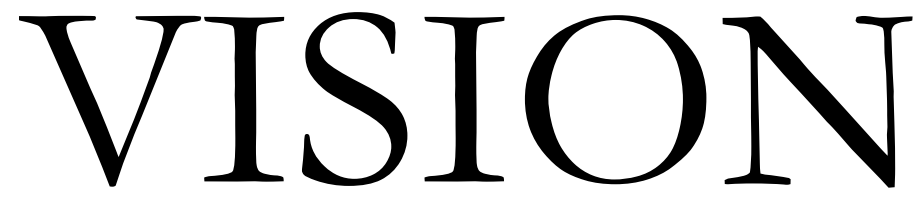

Journal for Language and Foreign Language Learning

Journal Vision, Volume 3 Number 2, October 2014

\title{
Advisor
}

Darmuin

Chief of Editor

M. NaD Annury

\section{Board of Editor}

Siti Tarwiyah Lulut

Widyaningrum Fina

Sa adah

\section{Administrative Manager}

Sayyidatul Fadlilah

Published by:

English Department

Faculty of Tarbiyah and Teacher Training Walisongo

State Institute for Islamic Studies Semarang Jl. Prof.

Dr. Hamka Km. 2 Ngaliyan Semarang

Phone: 024-7601295 Fax: 024-7615387 


\section{CONTENTS}

EPISTHEMOLOGICAL STUDY OF TERATAI METHOD: NEW OFFER ON ARABIC LANGUAGE TEACHING METHODOLOGY FOR BEGINNERINTERMEDIATE LEARNER IN INDONESIA Naifah - 5

STUDENT - TEACHER INTERACTION:

A CASE OF THE SECOND YEAR OF STATE SENIOR HIGH SCHOOLS IN CEPU Andika Cahya Ari Wibowo - 25

IMPROVING STUDENTS READING COMPREHENSION BY USING KNOW, WANT TO KNOW, AND LEARN (KWL) TECHNIQUE

Pancarini Dyah Rahayuningsih \& Eka Wulandari - 43

THE APPROPRIACY OF ASSESSMENT

IN THE JUNIOR HIGH SCHOOL ENGLISH TEXT BOOKBASED ON THE 2013 CURRICULUM

Siti Tarwiyah - 55 
PROMOTING FUN LEARNING IN GRAMMAR CLASS THROUGH SONGS

Nuraeningsih - 69

\begin{abstract}
CTL MODEL TO ACTIVATE STUDENTS PARTICIPATION IN SPEAKING CLASS AT ENGLISH EDUCATION PROGRAM
\end{abstract}

Semi Sukarni - 79

UTILIZING LEARNING PLATFORM FOR PAPERLESS CLASSROOM

Wenty Dwi Yuniarti - 105

الترادف في اللغة العربية

MuDdah - 125

THE ANALYSIS OF M.A.K HALLIDAY S THEORY OF SYSTEMIC FUNCTIONAL LINGUISTIC AND ITS IMPACT TO DISCOURSE ANALYSIS AND GENRE-BASED APPROACH Mohammad Andi Hakim - 139 



\title{
EPISTHEMOLOGICAL STUDY OF \\ TERATAI METHOD: New Offer on Arabic \\ Language Teaching Methodology for Beginner- \\ Intermediate Learner in Indonesia
}

\author{
Naifah \\ FITK IAIN Walisongo \\ Naifahhasan@yahoo.com
}

\begin{abstract}
Even in our modern schools, it is not unusual to Dnd teachers whose practice is shaped primarily from their past experiences. In the traditional language teaching methods, teachers offer course materials in a classroom where students listen, take notes, copy materials, execute homework and complete assignments. In many cases lecturers fail to transfer knowledge to students effectively despite personally having sound technical knowledge in the subject area. However, the challenge that faces the education environment has always been to ensure that the teaching and learning process takes place effectively in a classroom environment. This paper focuses on the author s experiences in implementing an active method in Arabic language teaching to promote effective student learning. It explores speciDc pedagogical theories combined with school resources to improve the quality of teaching and student learning. A simpliDed educational method for improving the quality of the teaching and learning process is presented. The method called "Teratai suggested that the effectiveness of the teaching and learning process is depend on the effective facilitation of communication, involvement and interaction among students, teachers and course content. The article is intended to explore episthemological consepts, assumptions, approaches, constructions, and applications of Teratai method
\end{abstract}


in Arabic language teaching. The purpose of this discussion is to build the awareness of a variety of effective teaching ideas and techniques that a lecturer may consider in light of their current teaching styles and personalities.

Key words: Teratai Method, language learning methodology, episthemological study

\section{Background of the article}

The academic unrest I feel as a teacher in Islamic traditional shool (1999_2007) because of various teaching problems1 inspi- rate me to stake out a teaching method in accordance with the demands of the situation, namely Teratai2 method: Terampil Atur Nilai (skillfully set the value). As the name implies, the main pur- pose of this method is the optimization of the value of classroom achievement. Three learning theory is very inDuential in the forma-

tion of this method s character, namely Piaget s theory of cognitive

${ }_{1}$ Primarily (1) There are many complaints (difficult) for Arabic language subject, characterized by the low average value of learners. (2) $75 \%$ of Arabic teacher in schools both public and faith-based schools do not have the ideal standard as Arabic teacher. Look at Khoirul Adib, Peningkatan Keprofesionalan Guru Bahasa Arab SMA/MA/MTs) Se-Malang Raya Melalui Lesson Study (http://sastra.um.ac.id/?p=964, accessed from the internet at 7th of July 2009), p.1, (3) The number of students in class above ideal provisions for skill subjects, with heterogeneity level of language skills. (4) Much burdens faced by the students from various subjects in school (5) Inadequacy of the existence or the use of multimedia (6) Lack of vocabulary enrichment mentoring programs, (7) Class meeting time is limited, and (8) Need special tricks to support the use of the eclectic method in the class so its application is not anymore abused as a method of "semau gue", "seadanya" or "gado-gado". Look at Tayar Yusuf and Syaiful Anwar, Metodologi Pengajaran Agama dan Bahasa Arab, second ed. (Jakarta: Raja Grafindo Persada, 1997), p. 184.

${ }^{2}$ Synonyms with lotus, is a plant in the monotypic family Nelumbonaceae. The Linnaean binomial Nelumbo nucifera (Gaertn.) is the currently recognized name for this species, which has been classified under the former names, Nelumbium speciosum (Willd.) and Nymphaea nelumbo, among others. Names other than Nelumbo nucifera (Gaertn.) are obsolute synonyms and should not be used in current works. This plant is an aquatic perennial. Under favorable circumstances its seeds may remain viable for many years, with the oldest recorded lotus germination being from that of seeds 1,300 years old recovered from a dry lakebed in northeastern China. Look at http://en.wikipedia.org/wiki/Nelumbo_nucifera. 
Episthemological Study Of Teratai Method ... development3, meaningful learning theory of David Ausubel 4 and information processing theory. This is an effort to bring the method of experimental-empirical realm to be more readable in scientiDctheoretical scene. Therefore, the authors made a thorough research in terms of concepts, basic theory, epistemological foundation, the basic assumptions, approaches, and aplication procedures. The study was a qualitative descriptive study using philosophical and phenomenological approach. On the terms of terrain or data collection method, this research can be classiDed in the Library (Library Research). Furthermore, the methods of critical analysis applied in an attempt to describe, discuss and criticize the primer idea in developing a new model.S This article is an extract from the study. 6

${ }^{3}$ Jean Piaget (French: [30 pja3e]; 9 August 1896 - 16 September 1980) was a Swiss developmental psychologist and philosopher known for his epistemological studies with children. His theory of cognitive development and epistemological view are together called "genetic epistemology". Piaget placed great importance on the education of children. As the Director of the International Bureau of Education, he declared in 1934 that "only education is capable of saving our societies from possible collapse, whether violent, or gradual." Piaget created the International Center for Genetic Epistemology in Geneva in 1955 and directed it until his death in 1980. According to Ernst von Glasersfeld, Jean Piaget is "the great pioneer of the constructivist theory of knowing." Look at http://en.wikipedia.org/wiki/Jean_Piaget. Baeyah, Latar Belakang Jean Piaget (http:// teoripiaget.blogspot.com/ , p. 1. Joy A. Palmer, Fifty Modern Thinkers of Education: From Piaget to the Present (London: Routledge, 2001), p. 38.

${ }^{4}$ Ausubel was influenced by the teachings of Jean Piaget. Similar to Piaget's ideas of conceptual schemes, Ausubel related this to his explanation of how people acquire knowledge. "David Ausubel theorized that people acquire[d] knowledge primarily by being exposed directly to it rather than through discovery" (Woolfolk et al., 2010, p. 288) In other words, Ausubel believed that understanding concepts, principles, and ideas are achieved through deductive reasoning. Similarly, he believed in the idea of meaningful learning as opposed to rote memorization. In the preface to his book Educational Psychology: A Cognitive View, he says that "If [he] had to reduce all of educational psychology to just one principle, [he] would say this: The most important single factor influencing learning is what the learner already knows. Ascertain this and teach him accordingly" (Ausubel, 1968, p. vi) Through his belief of meaningful learning, Ausubel developed his theory of advance organizers. http://en.wikipedia.org/wiki/David_Ausubel

${ }^{5}$ Ibid., p. 21-25.

${ }^{6}$ Naifah, Pengembangan Metode Pembelajaran Bahasa Arab Tingkat Pemula-Menengah di Indonesia: Kajian Terhadap Tawaran Baru: Metode Teratai (Thesis) (Yogyakarta: Program Pascasarjana UIN Suka, 2010). 


\section{Terata; Methods: Nature and Main Objectives.}

Teratai (Terampil Atur Nilai) method is a method of learning that is applied when teachers want to trigger and make condition that learners gradually master the learning material, so that class grades can be targeted and realized. Stages core learning procedure in this method can be shortened by Mr. Expert: Memorize, Recall, Explanation, Practise, Personal Performance, and Test.

Levels of learners in this study follows the learner classiDcation divided into four levels, namely the level I / beginners (marh\} alah mubtadiDn), level II/ intermediate (marh $\}$ alah mutawassithah), level III (marh\}alah mutaqaddimah) dan level IV (marh\}alah nihD iyyah). 7 The use of Teratai method in higher priority is for the two Drst level, namely beginner and intermediate.

From several problems faced by beginner-intermediate level learners, average learners low values become the focus of concern of researchers. Satisfactory meaningful value can be obtained honestly by the learners, therefore, become the main target of this method. A high value is a normative evidence that Arabic subjects can they mastered. This simple goal setting is done with the following considerations:

1. The negative stigma that Arabic is difficult and frightening need to be broken down among basicintermediate learners in Indonesia.

2. The confidence of students and teachers will be increased with the increasing of class average value.

3. The time allocation of Arabic learning in schools and madrassas is not rational when faced with the necessity of teachers to shape students fully master the four mahdrah lugawiyah.

4. Learners love to the Arabic language will be grown, so that mental preparation to welcome the Arabic subjects at a higher

${ }^{7}$ M. Shalih Samak, Fannu al-TadrTs li al-Tarbiyah al-Lughawiyah wa an Thiba'atiha al-Maslakiyah wa Anmatiha al-'Amaliyah (Kairo: Dar al-Fikr al-Araby, 1998), p. 170-171. For more about the objectives of each level, look at Busyairi al-Madjidi, Metodologi Pengajaran Bahasa Arab: Penerapan Audio Lingual Method dalam All in One System (Yogyakarta: Sumbangsih Offset, 1994), p. 46-49. Lihat juga 'AlT al-H\}adTdi, Musykilat at-Ta'ITm al-Lugah al-'Arabiyyah Ii Gairi al-'Arab (Kairo: Dar al-Katibal-'Arabi li at\}- T\}aba'ah wa an-Nasyr, 1967), p. 129-131. 
level will also be awaken, as well as they have the passion to perform the Arabic language independently.

A good achievement of learning outcomes is still the strongest motivation in learning activities in schools for students. 8 Most of the students are very motivated to get a good Dgure in any performance. Value as a motivator is very relevant in the world of arabic learning. Of course when accompanied by a full awareness of all the parties that the value must be meaningful. In language learning, elements of assessment which includes cognitive, affective and psychomotor skills should be directly proportional to the language sills of the learners. Teratai method is speciDcally designed to address the learning problems such as the low value of the class average grade.

\section{Epistemological Foundation of Teratai Method}

According to Suriasumantri, epistemological foundation is one of the three fundamental things that are usually asked in any discussion of symptoms or the object of a science 9 This section aims to explain revitalization of Teratai method epistemology as a method of Arabic learning.

1. Scientifc Sources of Teratai method

Epistemology is generally acknowledged at least four types of knowledge based on its source, namely: (1) intuitive knowledge, (2) an authoritative knowledge, (3) knowledge of logi-

${ }^{8}$ In addition to numbers, act as a motivational factor are present, competition, egoinvolvement, tests, knowing the results of learning, praise, fear of punishment, personal desires, interests and know the learning objectives. Look at Sardiman A. M., interaksi dan Motivasi Belajar Mengajar, 9th ed. (Jakarta: Raja Grafndo Persada, 2001), p. 90-93. Besides the aforementioned motivator, Nasution added, a challenging task, fearing reproach, standard aspiration and pleasant atmosphere. Lihat S. Nasution M. A., Didaktik Asas-Asas Mengajar, frst edition (Jakarta: Bumi Aksara, 1995), p. 78-83.

9 The three things are (1) what is the nature of the symptoms / object (ontological basis), (2) how to get or cultivation of symptoms / object was (epistemological foundation), (3) what are the benefts of symptoms / object (axiological foundation). Azhari Ghalib, Landasan Ontologi, Epistemologi dan Aksiologi Manajemen Pendidikan (http:// azharighalib.wordpress.com/2008/06/07/ landasan-ontologi-epistemologi-dan-aksiologipragmatis/, accessed from internet at 12th of April 2010). 
cal and (4) empirical knowledge. In other words, the source of knowledge in general is the reason (ratio), experience (reality), revelation (religion), and intuition (inspiration, conscience) ${ }^{10}$

Lotus method derived from my actual experience as a teacher. In addition, this method is also based on 3 constructivism learning theory, namely: Piaget's theory of cognitive development, meaningful learning theory of David Ausubel and information processing theory. Each of the three theories carries signifcant implications in the Teratai method.

The following discussion will show the implications of the third theory on the formation and application of Teratai method.

- Piaget's Theory of Cognitive Development

In the following table, it can be compared between the important implications of Piaget's theory on learning in general, as well as on Teratai method.

\begin{tabular}{|l|l|l|}
\hline No. & General Implications & $\begin{array}{l}\text { Implications on the Teratai } \\
\text { method }\end{array}$ \\
\hline 1. & $\begin{array}{l}\text { Language and the way } \\
\text { children think is differ- } \\
\text { ent from adults. There- } \\
\text { fore, teachers teach } \\
\text { using appropriate lan- } \\
\text { guage to the way chil- } \\
\text { dren think. }{ }^{1}\end{array}$ & $\begin{array}{l}\text { Selection and delivery of } \\
\text { learning materials tailored to } \\
\text { the level of student thinking. } \\
\text { thency concerned has es- } \\
\text { tablished textbook, the mode } \\
\text { of delivery remains adapted to } \\
\text { their comprehension. }\end{array}$ \\
\hline
\end{tabular}

${ }^{10}$ Muhbib, Epistem010gi, p. 12. 


\begin{tabular}{|c|c|c|}
\hline 2. & $\begin{array}{l}\text { Paying attention to the } \\
\text { mental processes of } \\
\text { the students, not just } \\
\text { the results. Besides the } \\
\text { truth of their answers, } \\
\text { teachers understand the } \\
\text { process they used to ar- } \\
\text { rive at the answer. }\end{array}$ & $\begin{array}{l}\text { Teachers do not blame the } \\
\text { learners when they did false } \\
\text { because teachers understand } \\
\text { the process they used to arrive } \\
\text { at the answer. For example, } \\
\text { when they use the word man } \\
\text { (not ma) to ask "What s your } \\
\text { name? Or use la madza-mad- } \\
\text { za for the purpose of la ba'sa } \\
\text { bih. But the teacher immedi- } \\
\text { ately give corrections. }\end{array}$ \\
\hline 3. & $\begin{array}{l}\text { Give attention on the } \\
\text { active involvement of } \\
\text { learners in learning. } \\
\text { They were encour- } \\
\text { aged to fnd their own } \\
\text { knowledge. In physics } \\
\text { learning, Piaget's the- } \\
\text { ory can be applied to } \\
\text { conduct experiments. }{ }^{4}\end{array}$ & $\begin{array}{l}\text { In the Arabic language learn- } \\
\text { ing students are given plenty } \\
\text { of time to practice communi- } \\
\text { cation. Whether it's listening, } \\
\text { speaking, reading and writing. } \\
\text { When the practice of dialogue, } \\
\text { for example, they will fnd } \\
\text { themselves many expressions } \\
\text { that they really need. }\end{array}$ \\
\hline 4. & $\begin{array}{l}\text { Children will learn bet- } \\
\text { ter if they feel comfort- } \\
\text { able. Teachers should } \\
\text { help children to interact } \\
\text { with the environment } \\
\text { as well as possible. }\end{array}$ & $\begin{array}{l}\text { In the classroom, students are } \\
\text { given the opportunity to talk } \\
\text { and discuss with friends, es- } \\
\text { pecially at every "Practice } \\
\text { stage. }\end{array}$ \\
\hline
\end{tabular}




\begin{tabular}{|l|l|l|}
\hline 4. & $\begin{array}{l}\text { Materials to be studied } \\
\text { by children should be } \\
\text { felt new but not unfa- } \\
\text { miliar. }^{6}\end{array}$ & $\begin{array}{l}\text { Instructional materials select- } \\
\text { ed is not anymore material as } \\
\text { general grammar on students } \\
\text { get at madrasah diniyyah, but as } \\
\text { functional materials that they } \\
\text { use everyday in their mother } \\
\text { tongue. The difference, in this } \\
\text { study they were trained to use } \\
\text { the target language. }\end{array}$ \\
\hline 5. & $\begin{array}{l}\text { Understanding indi- } \\
\text { vidual differences in } \\
\text { developmental prog- } \\
\text { ress. All learners are } \\
\text { assumed through the } \\
\text { same developmental } \\
\text { sequence, but takes } \\
\text { place with different } \\
\text { speeds. Provide oppor- } \\
\text { tunities for children to } \\
\text { learn appropriate with } \\
\text { their stage of develop- } \\
\text { ment. }{ }^{7}\end{array}$ & $\begin{array}{l}\text { Thersonal per- } \\
\text { formance payment system } \\
\text { through the achievement book } \\
\text { development of each learner. }\end{array}$ \\
\hline \multicolumn{2}{|c|}{ of assistance } \\
\end{tabular}

Table 1: Implications of Piaget's theory on the characteristic of Teratai method

- David Ausubel s Meaningful Learning Theory

Meaningful learning theory of Ausubel stated that the learning process will bring meaningful results if the teacher in presenting new subject matter can connect it with relevant concepts that already exist in the structure of student cognition. ${ }^{11}$

${ }_{11}$ Azhie, Teori Belajar (http://neozonk.blogspot.com/200B/02/teori-belajar.html, 
For that, the Teratai method applied the principles of gradation in material selection and subject delivery process so that what is taught will not be far from the framework of learners understanding. Furthermore on communication practices, this activities are expected to be the way for them to convey meaning and ideas through Arabic language.

For example, in reference to the number of learning materials and objects from 1 to 10 , the teacher should have made sure that the students have mastered the vocabulary of singularplural from the last meeting. So, the teacher just told them to memorize numbers 1-10 (for objects Muzakar / masculine Drst, followed by numbers to objects mu annad / feminine). Then, the teacher describe the rules, so the learners can practice applying it to answer several questions from the teachers, such as 3 mosques, 5 books, 7 pens 9 cars and so on. Only when they had advanced a Dgure, they are welcome to use it to communication practice, whether written or oral (in person, in pairs or in groups)..

In functional communication practice usually they will Dnd by themselves the additional elements they need to be asked to the teacher. the teacher are always ready to provide the information as required. So, it should be underlined at the beginning that there is no element of material that is not understood by learners. It is important to be stressed so that learners will no doubt to carry it in communicative interactions that are always meaningful.

\section{- Information Processing Theory.}

Based on information processing theory, the process of information travel in the learners memory in the application of the Teratai method can be described by the picture below. 


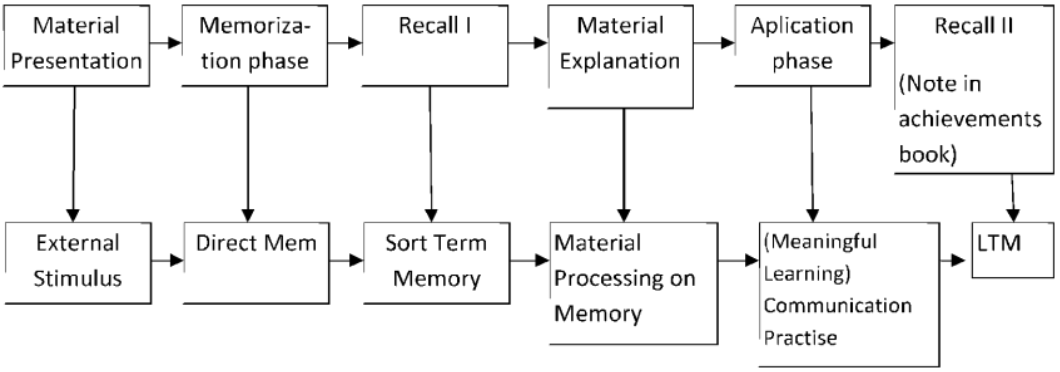

Figure 2: Information Journey Process of the Learners on the Aplication of Teratai Method.

\section{The Truth of Teratai Method}

According to epistimological experts and philosophers, to prove that a knowledge is true, one must frst analyze how, attitudes, and tools used to build the knowledge. There are several theories that explain the truth, among others, the following:

1. The correspondence theory of truth. According to the theory, the truth or the true situation is in the form of correspondence between the meaning intended by an opinion and what it is in fact.

2. The consistence theory of truth. According to the theory, the truth is not established on the relationship between the decision and something else, that is a fact or reality, but the relationship between the decisions themselves. In other words that the truth confrmed by the relationship between the new and the other decisions we have been seen and recognized frst.

3. The pragmatic theory of truth. The meaning of this theory is that the truth of utterance, proposition, or theory solely rely on the usage of it for humans life. ${ }^{12}$

Based on the three theories of truth above, the truth indication of the Teratai method can be seen in the following table.

12 Asta, Epistemologi, hlm 3. 
Episthemological Study Of Teratai Method ...

\begin{tabular}{|l|l|l|}
\hline No & Basic Reference & $\begin{array}{l}\text { The Truth Indication of the Tera- } \\
\text { tai Method }\end{array}$ \\
\hline 1 & $\begin{array}{l}\text { The correspon- } \\
\text { dence theory of } \\
\text { truth. }\end{array}$ & $\begin{array}{l}\text { Teratai method derived from the } \\
\text { teaching experience of the author } \\
\text { had documentational evidences. It } \\
\text { shows that this method actually have } \\
\text { been implemented and effective. } \\
\text { Briefly memorize together activities } \\
\text { as contained in the Teratai method is } \\
\text { not stress the students, but instead, } \\
\text { fun and have a positive impact. }\end{array}$ \\
\hline 2 & $\begin{array}{l}\text { The consistence } \\
\text { theory of truth }\end{array}$ & $\begin{array}{l}\text { Teratai method does not conflict } \\
\text { with existing theories in educa- tion. } \\
\text { The method is based on the 3 } \\
\text { language learning theory; Piaget's } \\
\text { theory of cognitive development, } \\
\text { David Ausubel meaningful learning } \\
\text { theory and the theory of informa- } \\
\text { tion processing. This method is also } \\
\text { the development of some existing } \\
\text { language learning methods. } \\
\text { Teratai method useful to ensure } \\
\text { mastery of the material and to target } \\
\text { student learning outcomes optimaly. }\end{array}$ \\
\hline 3 & $\begin{array}{l}\text { The pragmatic } \\
\text { theory of truth }\end{array}$ \\
\hline
\end{tabular}

Table 3 : The Truth Indication of the Teratai Method Based on the Three Theories of Truth

5. Approach and Design of Teratai Method in Arabic Language Learning.

1. As a contemporary language learning method, Teratai bases itself on the communicative approach.

2. Design of Teratai Method consist of the following elements; 
- The Aim of Teratai Method: To assist learners master the learning material briefy, carefully and get their best value.

- Syllabus and Language Learning Materials: Learning syllabus in accordance with the regulations, based on SBe. For the selection of materials, Teratai method recommends using communicative syllabus, but can also use Arabic learning materials that have been presented in textbooks.

- Types of Tasks and Learning Activities of Teratai Method: There are four main elements that characterize this method, the direct memorization, practical applications, frequently asked questions, and assessment of personal competence using performance books.

- The role of the student in the Teratai method is planning a program of their own learning, monitor and evaluate their own progress, interact with other members, learn from teachers, from students and from other teaching resources.

- The role of the teacher in the Teratai method

In the Teratai method, teachers act as "private tutor for learners. The duty of teachers is to deliver each learner to master the material and get the optimal value in a practical and fun way.

- The role of instructional material

The core functions of instructional materials have been selected and prepared by the teachers since the beginning of the semester is to clarify and simplify the student perspective on what should be mastered.

6. Aplication of Teratai Method in Arabic Language Learning.

Aplication of Teratai method in Arabic language learning can be reDected in the learning procedure which includes: Mr. Expert: Memorize, Recall, Explanation, Practise, Personal Performance, and Test.

The explanation of each step is as follows;

a. The teacher displays a word, phrase or sentence (and their meanings) that is an element of the expression that will be used in 
practise phase by the learners clearly. (Limit the number so can be memorized together in 5 or 10 minutes). 13 It is suggested to make this phase more interesting with media.14

b. After the teacher believes (based on a clear indication that all the learners can capture elements (eg by asking questions or ask one of the students to mention them once again fully), give class the command to memorize them together in 5 (or 10) minutes. For example, "Well, lets memorize them together in 5 minutes starting from: Now! At this stage, make sure that no students do other activities than memorization. This phase is called "Memorize .

c. After the time is up, the teacher gives the signal to end the memorize session. For example: "Done!

d. The teacher "recall the memory of the learners by creating a warm and pleasant atmosphere, beginning with the command "al-kitab mughallaq . Questions can be directed classically or personally with calling the name of the learner. Always use a Drm tone, but familiar and encouraging. If they can mention the exact answer, give positive comment, like; good, yak, jayyid, and so on. If there is someone too long thinking, interspersed with something refreshing like saying "Dorr or else. The session closed with questions from the teacher "Small? or "Easy? And approved by the class.

e. Explanation is the stage where the teachers act describes the use of language elements that have been memorized to communication practice or language material deepening. It is recommended that teachers use the selective phrase, modest and easy to understand. The timing is set around 5-15 minutes to

${ }^{13}$ Clarity of presentation of this information should be captured by all students, as it begins to enter the early stages of information processing theory..

${ }^{14}$ More complete discussion of instructional media look at Azhar Arsyad, Media Pembelajaran, p. 1-173. Also look at Sudarwan Danim, Media KOmunikasi Pendidikan: Pelayanan PrOfesiOnal Pemelajaran dan Mutu Hasil Belajar (Jakarta: Bumi Aksara, 1995), p. 1-23, Abdul Hamid dkk., Pembelajaran Bahasa, p. 157-227, Imam Asrori, Al-Wasa'il al-Mu'nat ff ta"ITm al-IArabiyyah (Malang: t.tp., 1995), p. 1-98. Muhbib Abdul Wahab, Epistem010gi, p. 251-286. 
keep the concentration of students. This stage concludes with questions and answers to ensure learners s understanding. Do not move the session before the teachers believe that they have understood very well what the teacher had explained.

f. Switch to the session "Practice, i.e. the time for students to apply the elements that have been memorized in communication practice, such as conversation, gramatical practise, arranging sentences, stringing phrases, composing dialogues, reading comprehension, and so on. Make sure and measure the mastery of the whole class by holding a question and answer.

g. Teachers invite one or a pair of students to show their ability to implement the teachers explanations in active (speaking or writing) or passive (listening and reading) communication, then the class together provide an evaluation of the performance. If necessary, invite the other learners to show practices being trained according to their own versions.

h. ) "Personal Performance phase can be done after school hours or at any other meeting. It is highly recommended that teachers provide speciDc hours, such as extracurricular hours to serve the personal performance. A special character of Teratai method is every learners have a book where the teacher note his performance and code the material they have mastered.

i. Teachers held a repetition session about material already mastered $80-100 \%$ by class in "Test phase.

1. Positions, advantages, disadvantages, and empowerment of Lotus Methods on practical methodological area of Arabic Language teaching for beginner-intermediate level in Indonesia

a. Teratai method position in the world of Arabic learning for beginner-intermediate level in Indonesia is as a new method which is an extension of some previous language learning methods.

b. Advantages and disadvantages of Teratai method can be seen in the following table. 


\begin{tabular}{|c|c|l|l|}
\hline No & Section & \multicolumn{1}{|c|}{ Advantages } & \multicolumn{1}{c|}{ Disadvantages } \\
\hline 1. & Material & $\begin{array}{l}\text { Suitable for per- } \\
\text { forming vocabulary } \\
\text { enrichment, short } \\
\text { sentence struc- } \\
\text { ture, short reading, } \\
\text { simple functional } \\
\text { conversation, or ma- } \\
\text { terial with defnitive } \\
\text { patterned. }\end{array}$ & $\begin{array}{l}\text { Less suitable for de- } \\
\text { thinking skills, such } \\
\text { as analyzing and } \\
\text { evaluating. }\end{array}$ \\
\hline 2. & $\begin{array}{l}\text { Learning } \\
\text { time }\end{array}$ & $\begin{array}{l}\text { Suitable for presen- } \\
\text { tation stage of new } \\
\text { material as well as } \\
\text { the strengthening } \\
\text { phase. } \\
\text { Time allocation of } \\
\text { learning stages is } \\
\text { clear, in order to } \\
\text { reach the effciency. }\end{array}$ & $\begin{array}{l}\text { Requires a little extra } \\
\text { of meeting time, } \\
\text { especially for per- } \\
\text { sonal performance } \\
\text { phase, when the } \\
\text { number of students } \\
\text { in a class more than } \\
\text { 25 people, in order to } \\
\text { get enough to service } \\
\text { them one by one. }\end{array}$ \\
\hline 3. & $\begin{array}{l}\text { Learners who are less } \\
\text { Learner are no more } \\
\text { readiness } \\
\text { learners who are } \\
\text { not ready for a new } \\
\text { material because te- } \\
\text { acher had performed } \\
\text { memorzze phase. } \\
\text { the memory may } \\
\text { face a little problem } \\
\text { at frst, but this only } \\
\text { occurs in a small } \\
\text { fraction of them. }\end{array}$ \\
\hline
\end{tabular}


Episthemological Study Of Teratai Method ...

\begin{tabular}{|c|c|c|c|}
\hline 4 & $\begin{array}{l}\text { Teachers } \\
\text { compe- } \\
\text { tention }\end{array}$ & $\begin{array}{l}\text { Not demanding a } \\
\text { qualifed speaking } \\
\text { skill or complex } \\
\text { methodological } \\
\text { competence. }\end{array}$ & $\begin{array}{l}\text { Requires teachers } \\
\text { patience and ad- } \\
\text { equate EQ (emotional } \\
\text { intelligence). Teratai } \\
\text { method is less suit- } \\
\text { able for teachers who } \\
\text { are not friendly and } \\
\text { can not break the ice, } \\
\text { because even though } \\
\text { the value target } \\
\text { will be achieved, } \\
\text { the stress effect for } \\
\text { students who are lazy } \\
\text { will be felt. }\end{array}$ \\
\hline 5. & $\begin{array}{l}\text { Achie- } \\
\text { vement } \\
\text { book }\end{array}$ & $\begin{array}{l}\text { Can be a motivator } \\
\text { and a means of per- } \\
\text { sonal relationships } \\
\text { between teachers- } \\
\text { learners } \\
\text { Being a control } \\
\text { means of students } \\
\text { competency, both } \\
\text { personally and clas- } \\
\text { sically. }\end{array}$ & $\begin{array}{l}\text { Learners who are do } \\
\text { not like to compete } \\
\text { have to be warned to } \\
\text { master the material } \\
\text { step by step. } \\
\text { Achievement books } \\
\text { arranged and f- } \\
\text { nanced by the teach- } \\
\text { er. }\end{array}$ \\
\hline 6. & $\begin{array}{l}\text { Mastery } \\
\text { of skills }\end{array}$ & $\begin{array}{l}\text { Learners feel easy to } \\
\text { recall learning ma- } \\
\text { terials, because after } \\
\text { school hours there } \\
\text { is always a mate- } \\
\text { rial that has been } \\
\text { acumulated in their } \\
\text { memory. } \\
\text { Achieved through } \\
\text { easy but surely } \\
\text { phasing. }\end{array}$ & $\begin{array}{l}\text { Depends on the live- } \\
\text { liness of the students } \\
\text { because teachers only } \\
\text { explain briefy (in } \\
\text { "explanation phase), } \\
\text { gives the correc- } \\
\text { tion (in "practice } \\
\text { phase) and provide } \\
\text { questions to detect } \\
\text { material absorption } \\
\text { (in "personal perfor- } \\
\text { mance" phase). }\end{array}$ \\
\hline
\end{tabular}


Episthemological Study Of Teratai Method ...

\begin{tabular}{|l|l|l|l|}
\hline 7. & $\begin{array}{l}\text { Learning } \\
\text { out- } \\
\text { comes }\end{array}$ & $\begin{array}{l}\text { Can be calculated } \\
\text { and the maximum } \\
\text { targeted by empow- } \\
\text { ering the achieve- } \\
\text { ment book optimally. } \\
\text { The class average } \\
\text { grade is relatively } \\
\text { much higher than } \\
\text { the application of } \\
\text { the eclectic method } \\
\text { without details of } \\
\text { the method. }\end{array}$ & $\begin{array}{l}\text { Have not been able } \\
\text { to achieve high } \\
\text { learning outcomes } \\
\text { for students who } \\
\text { suffer from psycho- } \\
\text { logical disorders or } \\
\text { behavioral deviation } \\
\text { (usually around 1-5 } \\
\text { personnel in a class- } \\
\text { room containing 30 } \\
\text { students), but enough } \\
\text { to make them under- } \\
\text { stand the meaning of } \\
\text { "attempt } .\end{array}$ \\
\hline
\end{tabular}

Table 2: Advantages and disadvantages of Teratai method

c. In the Deld of methodology, Teratai method can be used as a major variant in the application of the eclectic method in schools where students are expected to master the lessons and get a high score on each test, furthermore at the end of semester.

\section{Closing}

That's all a brief overview of Teratai method. This method is recommended to be choosed every explore new topics in class, in order to ensure the readiness of students to receive a new language learning material. For strengthening phase, you should use a variety of language games so that students do not fnd the same atmosphere of the class twice in a row, but intermittent.

Arabic is like any other language, easy in some aspects and hard in some others. It depends on the learners background and ability to adapt to new rules. May this method helps the learners to improve their ability. 


\section{REFERENCES}

Adib, Khoirul. Peningkatan KeproJesionalan Guru Bahasa Aral SMAIMAIMTs) Se-Malang Raya Melalui Lesson Stud) (http://sastra.um.ac.id/?p=964, accessed from the internet at 7 th of July 2009).

David Ausubel (http://en.wikipedia.org/wiki/David_Ausubel, accessed from the internet at 21 st of Jun 2010).

Arsyad, Azhar. Media Pembelajaran, p. 1 173. Lihat juga Sudarwan Danim, Media Komunikasi Pendidikan: Pela)anan Profesional Pembelajaran dan Mutu Hasil Belajar (Jakarta: Bumi Aksara, 1995).

Asrori, Imam. Al-Was0 il al-Mu JnOt $f$ tallm al-Arabi))ab (Malang: t.tp., 1995).

Azhie, Teori Belajar (http://neozonk.blogspot.com/2008/02/ teori-belajar.html, accessed from the internet at 21st of Jun 2010)

Baeyah, Latar Belakang Jean Piaget (http:/ / teoripiaget.blogspot.com/ accessed from the internet at 20th of Jun 2010).

Edward de Bono, Teach Your Child How to Think ( Revolusi BerGkir), terj. Ida Sitompul dan Fahmi Yamani, cet. ke-2 (Bandung: Penerbit Kaifa, 2007).

Ghalib, Azhari. Landasan Ontologi, Epistemologi dan Aksiologi Manajemen Pendidikan (http:/ /azharighalib.wordpress. /2008/06/07/ landasan-ontologi-epistemologi-dan-aksiologi-pragmatis/, accessed from the internet at 12th of April 2010).

H) adDdi, 'AlD al-. Mus)kil0t at-Ta IIm al-Lugah al-Arabi))ab li Gairi alArab (Kairo: DOr al-K0tibal-Arabi li at\}-T\}ab0 ab wa an-Nas)r, 1967). 
KhOlidy, Ah\}mad S0mih\} al-. ArkDn at-Tadr)s cet. ke-2 (Palestina: Markaz al-Qat\}Dn li al-Bab\}Di wa at-Tat\}wDr at-Tarbany; Mu assasah Abd al-Mub\} sin al-Qat $\}$ Dn, 2002).

Lawrence C. dan Manning R. Menjaga Otak. Anda Tetap Hidupj cet. ke-1( Yogyakarta: Penerbit Think, 2009).

Madjidi, Busyairi al-. Metodologi Pengajaran Bahasa Arab: Penerapan Audio Lingual Method dalam All in One System (Yogyakarta: Sumbangsih Offset, 1994).

Naifah, Pengembangan Metode Pembelajaran Bahasa Arab Tingkat PemulaMenengah di Indonesia: Kajian Terhadap Tawaran Baru: Metode Teratai (Thesis) (Yogyakarta: Program Pascasarjana UIN Suka, 2010).

Palmer, Joy A. Fifty Modern Thinkers of Education: From Piaget to the Present (London: Routledge, 2001).

S. Nasution M. A., Didaktik Asas-Asas Mengajar, 1st ed. (Jakarta: Bumi Aksara, 1995).

Samak, M. Shalih. Fannu al-TadrDs li al-Tarbiyah al-Lughawiyah wa an ThibD DtibD al-Maslakiyah wa AnmDtiha al-Amaliyah (Kairo: Dar al-Fikr al-Araby, 1998).

Sardiman A. M., Interaksi dan Motivasi Belajar Mengajar, 9th ed. (Jakarta: Raja GraDndo Persada, 2001

Trianto, Model-model Pembelajaran Inovatif Berorientasi Konstruktivistik: Konsepj Landasan Teoritis-Praktis dan Implementasinya, Drst ed. Jakarta: Prestasi Pustaka, 2007.

Yusuf, Tayar and Syaiful Anwar, Metodologi Pengajaran Agama dan Bahasa Arabj second ed. (Jakarta: Raja GraDndo Persada, 1997). 
